\title{
Surface Alteration in Aging of Rat Tubae Uterinae Epithelium
}

\author{
Şule Şahin1', Gülnur Take Kaplanoğlu¹, Deniz Erdoğan¹, Mahmud Bağırzade1, Zekiye Suludere² \\ ${ }^{1}$ Department of Histology and Embryology, Faculty of Medicine, Gazi University, Ankara, Turkey \\ ${ }^{2}$ Department of Biology, Faculty of Science, Gazi University, Ankara, Turkey
}

\section{ABSTRACT}

Objective: Aim of the study was evaluating arrangement of apical surface differentiation in cross-sections of tuba uterinae in different age groups by scanning electron microscope.

Material and Methods: Six groups were created with 36 Wistar rat; $1^{\text {st }}$ group: neonate $\left(1^{\text {th }}\right.$ day) $(n=6), 2^{\text {nd }}$ group: young (22 ${ }^{\text {nd }}$ day) ( $\left.n=6\right), 3^{\text {rd }}$ group: prepubertal (4-6 week) $(n=6), 4^{\text {th }}$ group: adult $\left(10\right.$ week) $(n=6), 5^{\text {th }}$ group: premenopausal $\left(8\right.$ month) $(n=6), 6^{\text {th }}$ group: old $(18-20$ month) $(n=6)$. Tissue samples examined with scanning electron microscope.

Results: When surface differentiations of epithelial cells in tubae uterinae from birth to menopause were considered, it was determined that the cell with microvilli are first maturing cells and degenerated by ages first. It was observed that the ciliated cells are last maturing cells and subsisting as a mature cell during the postmenopausal period.

Conclusion: Towards the menopause degeneration in microvillous cells together with lack of secretion may affect sperm nutrition adversely. The increase of ciliated cells in aging may be a physiological result related to the active role of cilia movement in the sperm and early embryo transport against a probable decrease in muscle contraction in aging.

Key Words: Tubae Uterinae, epithelium, aging, scanning electron microscop, rat

Received: 24.01.2012 Accepted: 15.06.2012

\section{Introduction}

Tubae Utarinae play a critical role in reproductive function; holding of the ovum thrown from ovary through ovulation, similarly transmiting sperm which does not have the ability to fertilize the ovum, and during this period ensuring the sperm gain the ability to fertilize are among the duties of the tubae utarinae. Also, it has an appropriate structural medium for fertilization and with this feature it is an organ in which fertilization occurs (1-3).

Tubae uterinae epithelium begins to differentiate between postnatal $5^{\text {th }}-10^{\text {th }}$ days and the number of cilia in ciliated cells increases. The secretory cells without cilia differentiate approximately in the $23^{\text {rd }}$ day. Besides the cyclic changes in the effect of sex hormones, morphologic changes are observed in the epithelium surface along with aging. Throughout the tubae uterinae, mostly in fimbria, the rate of ciliated cells has increased, on the other hand there is no significant difference between the follicular and luteal phases of the menstrual cycle. However, specifically, a few ciliated cells are determined in all parts of postmenopausal tubae uterinae. The size and shape of the surface bulges of cells which secrete change in connection with cell surface activity during the menstrual cycle. In the postmenopausal period the do- mes are small, nearly flat and the microvilli are short and rare $(4,5)$.

Through literature, no study in which the whole development process of tubae uterinae was examined by using the fertility period as base has been found. Because embryo development during the preimplantation period occurs in tubae uterinae and surface changes in tubae uterinae are related to the changes in cells within the epithelium, it was thought that determining surface changes and distribution of the ciliated cells in tubae uterinae epithelium would be important. For that purpose, the distribution of the ciliated cells and nonciliated cells in tubae uterinae epithelium and surface changes in parallel with age were determined in rats of various age groups, by scanning electron microscope.

\section{Material and Methods}

\section{Experimental animals}

In this study, 6 groups composed of 36 Wistar rats were formed; $1^{\text {st }}$ group: neonate ( $1^{\text {th }}$ day) $(n=6), 2^{\text {nd }}$ group: young $\left(22^{\text {nd }}\right.$ day) $(n=6), 3^{\text {rd }}$ group: prepubertal (4-6 week) $(n=6), 4^{\text {th }}$ group: adult (10 week) $(n=6), 5^{\text {th }}$ group: premenopausal (8 month) ( $n=6), 6^{\text {th }}$ group: old (18-20 month) $(n=6)$. Our study has been approved by Gazi University Experimental Animals Ethics Committee. 
The tissue samples which belong to the appropriate periods underwent a common following up method for the purpose of being examined under the scanning electron microscope.

\section{Scanning electron microscopic method}

The tissues obtained were fixed in buffered glutaraldehyde for 24 hours. Then, they were kept in 1\% osmium tetroxide solution as active for 1 hour. After their second fixation with osmium tetroxide, they underwent acetone series baths which have increasing degrees $(25 \%, 50 \%, 75 \%, 100 \%)$ so as to remove excess water from the tissue.

After dehydratation, by means of making a pressure on the tissue surface with liquid carbon dioxide the tissues were critical-point dried. Then the tissues were placed in stubs. After that, their encrusting with gold dust for making them conductive and their pictures were taken by examining them under JEOL JSM-6060LV scanning electron microscope.

\section{Results}

In the SEM pictures of tubae uterinae which belong to the neonate, when an ampulla section was considered, it was seen that typical mucous folds of this section had not yet taken shape (Figure 1A). In the examinations under high magnification, it was determined that the epithelium comprised largely of microvillous cells (Figure 1B). It was seen that the secretory microvillous cells were short and irregular, microvilli precursors which had not yet taken shape formed the bubble-shaped evaginations (Figure 1C).
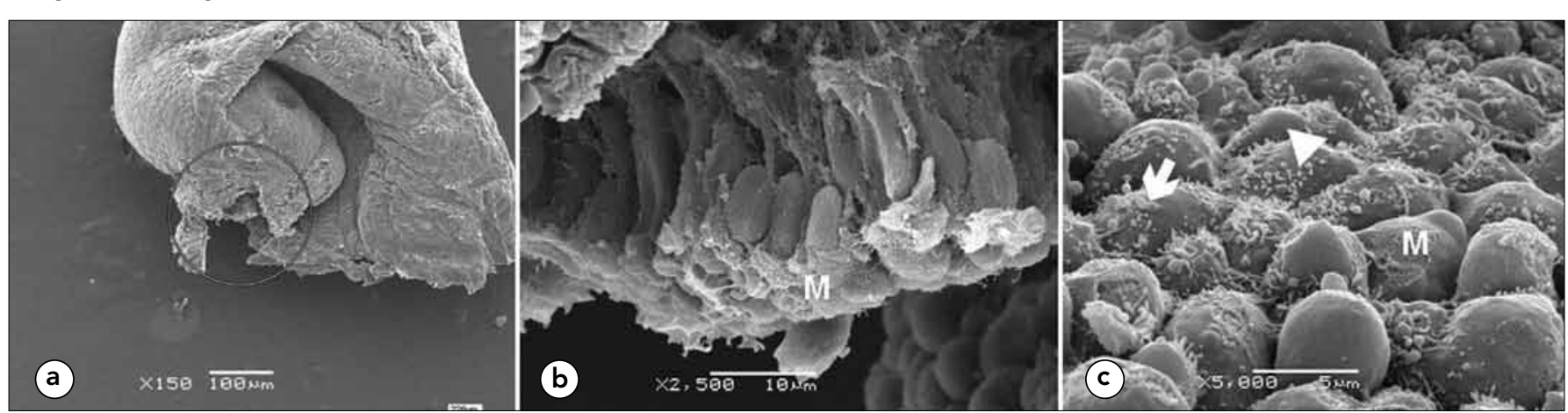

Figure 1a-c. The cross section of the neonate tubae uterinae M: The microvillous cells, $\rightarrow$ : The bubble shaped evagination, $\nabla$ Irregular microvilli (AX150, BX2500, CX5000)
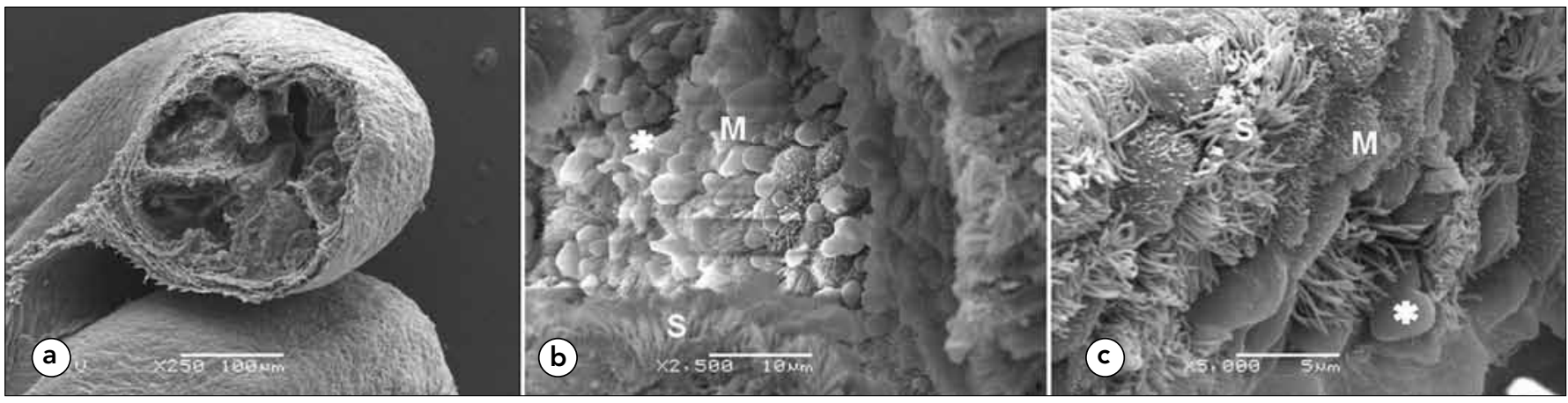

Figure 2a-c. The cross section of the young tubae uterinae

M: The microvillous cells, S: Ciliated cells, $*$ : The microvillous cells made fingerlike projection into the lumen (AX250, BX2500, CX5000) 
mulated on surfaces of the microvillous cells was observed. The ciliated cells were definite with their long cilia which had a regular course (Figure 4B). It was observed that the apical surface of a group of microvillous cells changed and protruded like a dome towards the lumen. It was observed that there were no microvilli on the surface of fingerlike processes ( $\mathrm{Fi}$ gure $4 \mathrm{C})$.

In the examination of tubae uterinae which belong to the premenopausal period, at low magnification, the ampulla was distinguished (Figure 5A). On examination under high magnification, it was seen that, while the ciliated cells were more common when compared with the other cells, microvillous cells were dominant throughout the cross section. While there
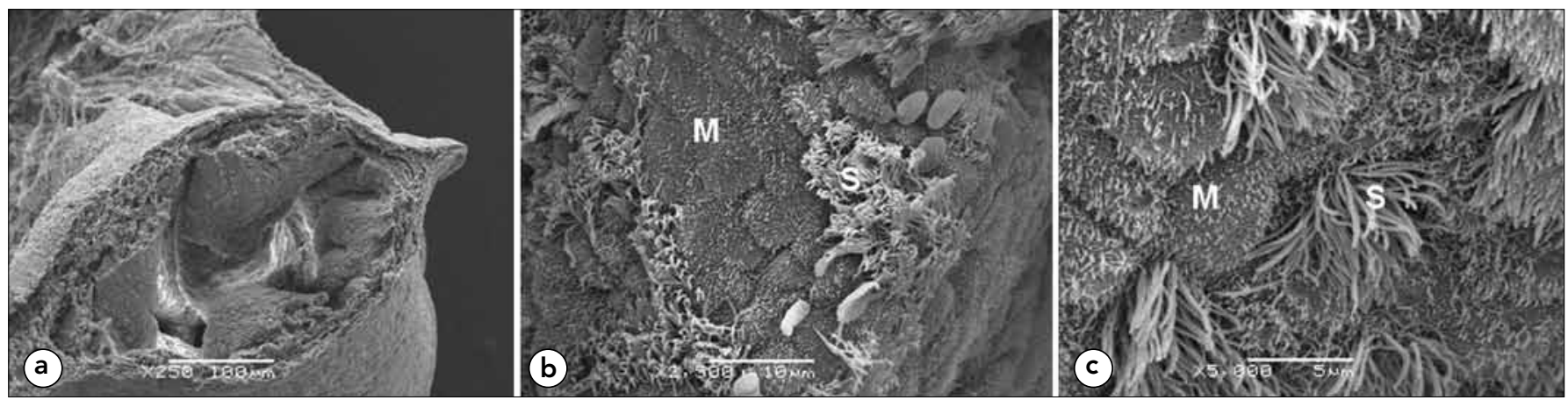

Figure 3a-c. The cross section of the prepubertal tubae uterinae

M: The microvillous cells, S: Ciliated cells (AX250, BX2500, CX5000)
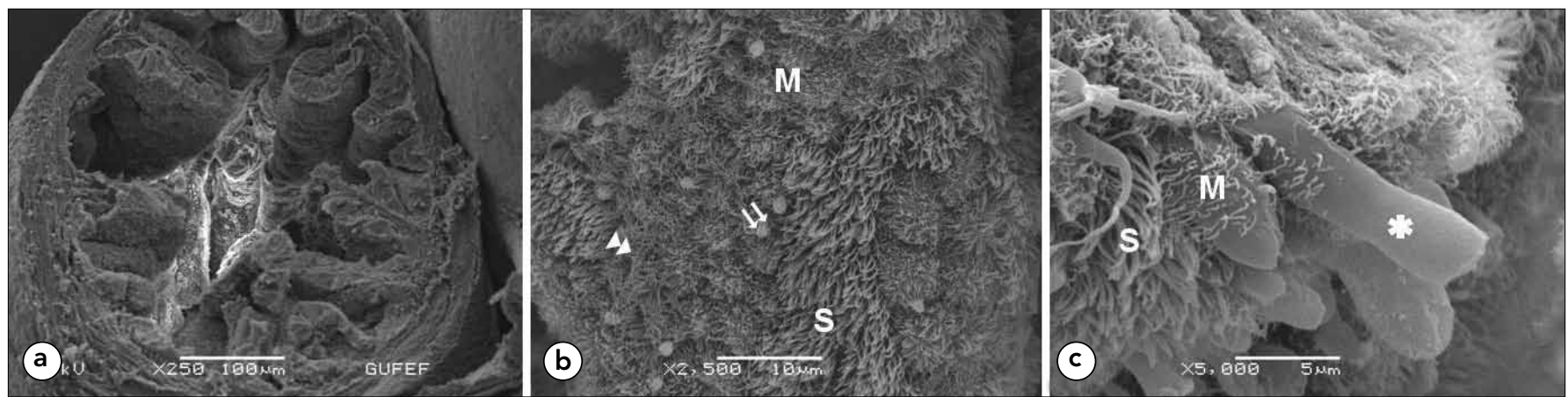

Figure 4a-c. The cross section of the adult tubae uterinae

M: The microvillous cells, S: Ciliated cells, $\uparrow \uparrow:$ the secretion material accumulated on the surfaces of the microvillous cells, $":$ the microvilli like web, $\star$ : The microvillous cells made fingerlike projection into the lumen (AX250, BX2500, CX5000)
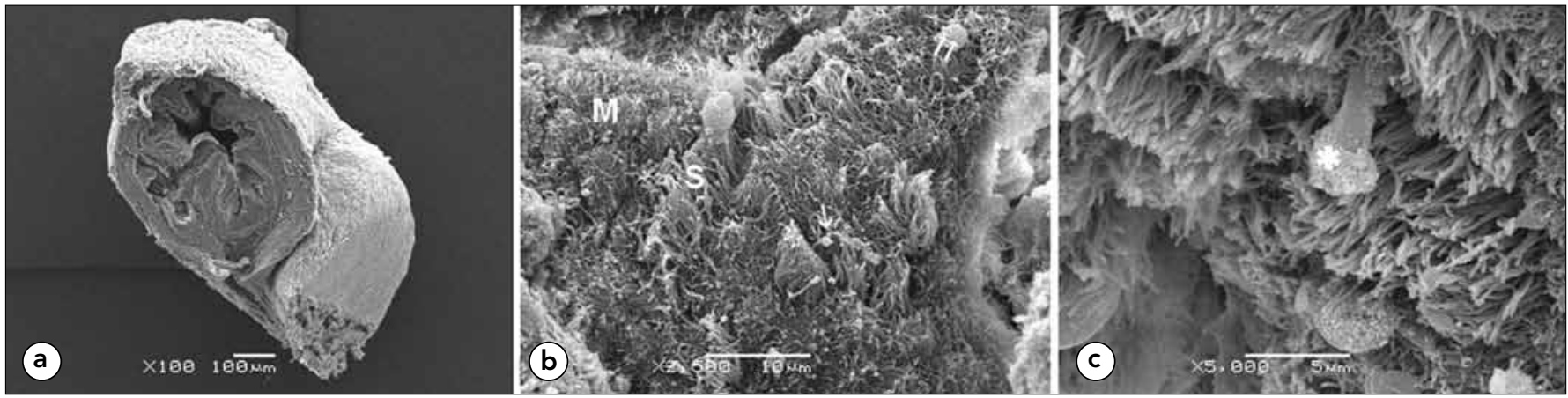

Figure 5a-c. The cross section of the premenopausal tubae uterinae

M: The microvillous cells, S: Ciliated cells, $\uparrow \uparrow:$ the secretion material accumulated on the surfaces of the microvillous cells, $\rightarrow:$ The domes observed on the heads of the cilia. *: The microvillous cells made fingerlike projection into the lumen (AX150, BX2500, CX5000) 

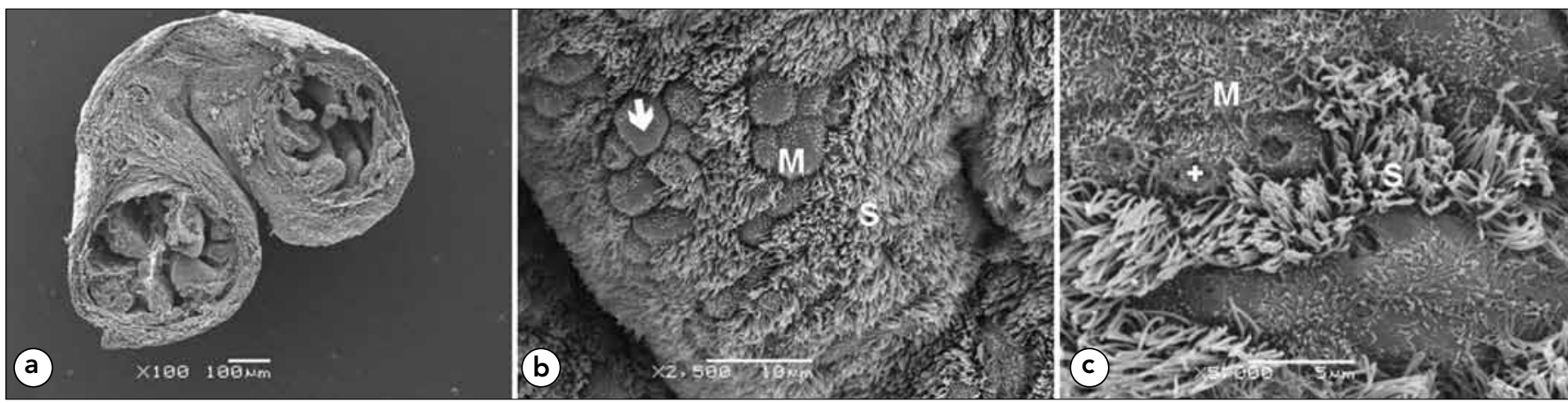

Figure 6a-c. The cross section of the postmenopausal tubae uterinae

M: The microvillous cells, S: Ciliated cells, $\rightarrow$ : short irrugular and blunted microvilli, $+:$ The microvillous cells whith apical surface deformation (AX150, BX2500, CX5000)

more common. In this group, the most definite change was observed in the microvillous cells. The form of the microvilli was corrupted and erased from place to place and blunted (Figure 6B). In some areas it was also determined that there was deformity in the apical cell membrane of the cells (Figure 6C).

In conclusion, in this study surface differentiations of epithelial cells in tubae uterinae were evaluated. It was determined that microvillous cells are the first maturing cells and the cell form which degenerates first in aging. It was considered that, towards the menopause, lack of secretion together with the degeneration in microvillous cells may affect sperm nutrition adversely. In this study, it was observed that the ciliated cells are the last maturing cells and exist as mature cells during the postmenopausal period. It was considered that this result was a physiological result of the active role in which cilia movement played a role in sperm and early period embryo transport against a probable decrease in muscle contraction in aging.

\section{Discussion}

Tubae uterinae which differentiate from the paramesonephric canal around the $7^{\text {th }}$ week of growth have critical importance in transport of germ cells, fertilization and growth of the early embryo. Its epithelium is monolayered and columnar, it consists of two basic cells: the ciliated cells and secreting cells $(3,5)$.

In a study which was made in 1994, it was determined that, in the $3^{\text {rd }}-4^{\text {th }}$ months rats were sexually matured, distribution of the non-ciliated cells during ovulation was much greater in the ampulla and isthmus when compared with the preampullar section, and the majority of the epithelial cells in the isthmus had no cilia. During electron microscopic examination, sectional differences were observed in the fine structure of Peg cells which produce a secretion. It was observed that the non-ciliated cells in fimbria made the dome into the lumen, cytoplasms of ampulla and isthmus were basophilic. Also, two types of secretory cells were observed in the fimbria. In the first type, there are electron-lucent granules, making a definite dome in apical cytoplasm and electron-dense granules under the nucleus area. In the second type a many medium electron dense secretory granules locate in the area up to nucleus, and electron dense granules are few. While the first type has been observed in fimbrial epithelium, the second type has been observed in fimbria and infundibulum area (6).

In this study, when the ampullary area was evaluated under scanning electron microscopy it was determined that the ciliated cells increased with aging, as distinct from the literature, and microvillous secretory cells in young and adult groups in the ampulla area made apical evaginations. This finding was evaluated as a result of increasing secretion for sperm nutrition during the reproductive period in the ampulla which is the important area for the fertilization.

In the literature, it was determined that the changes in the menstrual cycle of tubae uterinae in various mammal groups had been examined under transmission and scanning electron microscopes in the studies made until the present $(7,8)$.

Abe and colleagues examined the surface, above the lumen, of epithelial cells in the different sections of goat tubae uterinae throughout the follicular and luteal phases of the menstrual cycle at the level of the scanning electron microscopy. Quite a lot of cilia which are equal in height and distributed regularly were observed in the fimbria at the follicular phase on the surface of the epithelium. Cilia hide the apical surfaces of the non-ciliated cells. The apical projection on the surface of non-ciliated cells in the fimbria in the luteal phase drew attention. Cilia were hidden by this surface projection of the non-ciliated cells. The microvilli were not observed throughout the luteal phase in many of the surface projections of the non-ciliated cells. The epithelium in the follicular phase in the ampulla has cilia on a large scale. The cilia are higher than the surface projection of the non-ciliated cells. The nonciliated cells have slightly swollen surfaces and definite microvilli. The cilia in the ampulla in the luteal phase have been masked by the surface projection of non-ciliated cells which include short microvilli. In the isthmus in the follicular phase, the apical surface of the non-ciliated cells has short microvilli and their surface is flat or slightly swollen. In the luteal phase the apical projections of the non-ciliated cells in the isthmus are highly round and the number of the microvilli is fewer than the number of the microvilli in the follicular phase. It was stated that in the intramural section, the apical surface of the non-ciliated cells throughout the follicular and luteal phases was nearly flat and a several short microvilli were seen on the surface (5). 
Crow and colleagues examined the changes in the epithelium throughout all the sections of tubae uterinae in women who are in different phases of the menstrual cycle in terms of morphology in the dimension of the fine structure. A few ciliated cells were definitely determined in all sections of postmenopausal tubae uterinae. The size and shape of the surface domes of the secretory cells changed in parallel with the cell surface activity throughout the menstrual cycle. It was determined that the domes in the postmenopausal period were small, nearly flat and the microvilli were short and rare. In the pictures taken with the scanning electron microscope, it was established that the ciliated cells had relatively flatter surface when compared with the other cells. Throughout the follicular phase, definite domes and irregular fingerlike projections were observed. It was stated that this surface activity peaked in the pre-ovulation phase, surface projections became evident, moreover some of them were taller than the cilia of the neighbouring cells. It was notified that surface activity during the ovulation changed, with the surface domes becoming flat in the early and mid-luteal phase and surface domes became definite again in the late luteal phase (4).

The same researchers also examined the epithelial cells surface above the lumen of the tubae uterinae in pig and cow throughout the follicular and luteal phase of the estrous cycle at the level of the scanning electron microscope and obtained similar results $(9,10)$.

In the age related studies examined by scanning electron microscopy, the cell with microvilli appeared flattened, the microvilli were shortened, and also microplica like formation occurred in the cells, especially in the postmenopausal period.

According to the researchers; microplicae-like structures, associated with other regressive changes, represent an important adaptation of the epithelium of the fallopian tube; these are probably induced by the physiological process of aging, thus better withstanding hormonal changes associated with the advent of the menopause. The deciliation occurred in the all female genital organs, and it also emphasized that it occurred most prominently in tuba uterina (11-13).

In this study, besides the findings of researchers, it was determined that the rate of the ciliated cells increased in the postmenopausal period. However, in parallel with the findings of the researchers, the deformity and erasure in the apical surface differentiations of the microvillous cells drew attention. However, in contrast to the literature, we have not observed micro-plicae formation in micovillous cells in our study. In addition, it was seen that there was deformity in the cilia arrangement in premenopausal and postmenopausal periods, the cilia which have the swollen heads took shape. It was thought that this arrangement and structural deformity might be connected with the decrease in hormone level in aging.

Nayak and colleagues examined the changes showed throughout the menstrual cycle in the ciliated and secretory cells in the infundibular section of tubae uterinae in female sheep. The cross sections taken from the infundibulum section of tubae uterinae in the $1,2,3,9,10,12$ and $16^{\text {th }}$ day of the menstrual cycle were examined under the electron microscope. Presence of the cilia throughout the estrous cycle was proved and in no phase of this cycle, was deformity or loss in cilia observed. It was notified that small cilia bunches were observed especially in the $1^{\text {st }}$ day of the cycle. This is proof of active cilia formation through the follicular phase. It was established that the secretory cells showed typical cytologic changes in connection with the phases of the estrous cycle and these changes occurred mostly during the follicular phase. It was stated that, in this phase, the secretory cells had a full-grown granulated endoplasmic reticulum, many ribosomes, secretory granules in various form, density and size (14). Consequently in this study, definite changes in the secretory cells in reproductive phases were observed and this situation supports our findings. We consider that the apical surface evaginations in the microvillous cells which we examined in our study are probably the result of secretion accumulations in the cells.

In our study, as distinct from the literature, the surface changes in the tubae uterinae ampulla section during the critical periods in terms of the hormone were examined under the scanning electron microscope. In consequence of the study, it was determined that microvillous cells are the first maturing cells and the cell form which degenerates first in aging, and the ciliated cells are the last maturing cells and exist as a mature cell during postmenopausal period.

\section{Conclusion}

Our findings suggest that, towards the menopause, degeneration in the microvillous cells, together with lack of secretion, might affect sperm nutrition negatively. The increase in the ciliated cells in aging might be a physiological result of the active role which the cilia movement plays in sperm and early embryo transport against the possible decrease in muscle contraction in aging.

\section{Conflict of Interest}

No conflict of interest was declared by the authors.

\section{References}

1. Safwat MD, Habib FA, Oweiss NY. Distribution of macrophages in the human fallopian tubes: an immunohistochemical and electron microscopic study. Folia Morphol (Warsz) 2008;67:43-52.

2. Yaniz JL, Lopez-Gatius F, Hunter RH. Scanning electron microscopic study of the functional anatomy of the porcine oviductal mucosa. Anat Histol Embryol 2006;35:28-34. [CrossRef]

3. Umezu T, Tomooka Y. An evidence of stromal cell populations functionally linked with epithelial cell populations in the mouse oviduct. Zoolog Sci 2004;21:319-26. [CrossRef]

4. Crow J, Amso NN, Lewin J, Shaw RW. Morphology and ultrastructure of fallopian tube epithelium at different stages of the menstrual cycle and menopause. Hum Reprod 1994;9:2224-33.

5. Abe H, Onodera M, Sugawara S. Scanning electron microscopy of goat oviductal epithelial cells at the follicular and luteal phases of the oestrus cycle. J Anat 1993;183:415-21.

6. Abe H, Oikawa T. Regional differences in the ultrastructural features of secretory cells in the golden hamster (Mesocricetus auratus) oviductal epithelium. J Anat 1991;175:147-58.

7. Odor DL, Gaddum-Rosse P, Rumery RE. Secretory cells of the oviduct of the pig-tailed monkey, Macaca nemestrina, during 
the menstrual cycle and after estrogen treatment. Am J Anat 1983;166:149-72. [CrossRef]

8. Verhage HG, Mavrogianis PA, Boice ML, Li W, Fazleabas AT. Oviductal epithelium of the baboon: hormonal control and the immuno-gold localization of oviduct-specific glycoproteins. Am J Anat 1990;187:81-90. [CrossRef]

9. Abe H, Oikawa T. Observations by scanning electron microscopy of oviductal epithelial cells from cows at follicular and luteal phases. Anat Rec 1993;235:399-410. [CrossRef]

10. Abe H, Oikawa T. Examination by scanning electron microscopy of oviductal epithelium of the prolific Chinese Meishan pig at follicular and luteal phases. Anat Rec 1992;233: 399-408. [CrossRef]
11. Makabe S, Motta PM, Naguro T, Vizza E, Perrone G, Zichella L. Microanatomy of the female reproductive organs in postmenopause by scanning electron microscopy. Climacteric 1998;1:63-71. [CrossRef]

12. Myers RK, Cook JE, Mosier JE. Comparative aging changes in canine uterine tubes (oviducts): electron microscopy. Am J Vet Res 1984;45:2008-14.

13. Correr $S$, Makabe $S$, Heyn R, Relucenti M, Naguro T, Familiari G. Microplicae-like structures of the fallopian tube in postmenopausal women as shown by electron microscopy. Histol Histopathol 2006;21:219-26.

14. Nayak RK, Albert EN, Kassira WN. Cyclic ultrastructural changes in ewe uterine tube (oviduct) infundibular epithelium. Am J Vet Res 1976;37:923-33. 